\title{
Wider Boundaries: The Welfare State and International Remittances
}

\author{
J. Atsu Amegashie \\ Michael Batu
}

CESIFO WORKING PAPER NO. 5456

CATEGORY 1: PUBLIC FinANCE

JULY 2015

An electronic version of the paper may be downloaded

- from the SSRN website:

- from the RePEc website:

- from the CESifo website:

wWw.SSRN.com

Www.RePEc.org

www.CESifo-group.org/wp 


\title{
Wider Boundaries: The Welfare State and International Remittances
}

\begin{abstract}
Recent theoretical work shows that precautionary savings increase in response to an increase in first-order risk. In addition, it is known that the welfare state, being an insurance or consumption-smoothing mechanism, reduces the negative welfare effect of future income uncertainty. We build a model of remittances and savings under income uncertainty and show that an immigrant will increase his remittances in response to a first-order risk decrease in future income. Using changes in the size and generosity of the welfare state as a measure of changes in future income risk, we empirically test the prediction of our model using panel data of bilateral remittances. Our theoretical prediction is supported by the data: there is a positive relationship between a more generous welfare state in host countries and international remittances (i.e., transfers beyond the borders of the welfare state) by immigrants. The boundaries of the welfare state are wider than previously thought.
\end{abstract}

JEL-Code: D130, E210, F220, F240, I380.

Keywords: first-order risk, immigrant, precautionary savings, remittances, welfare state.

\author{
J. Atsu Amegashie* \\ Department of Economics and Finance \\ University of Guelph \\ Canada - Guelph, Ontario N9B 3P4 \\ jamegash@uoguelph.ca
}

\author{
Michael Batu \\ Department of Economics \\ University of Windsor \\ Canada - Windsor, Ontario N9B 3P4 \\ mbatu@uwindsor.ca
}

*corresponding author

July 24, 2015

We thank Kurt Annen, Oliver Masakure, and Osman Ouattarra for comments. 


\section{Introduction}

Economic and population growth coupled with growing differences between OECD countries and the developing world have led to an increasing wave of cross-country migration over a long period of time. The over-riding motivation for migration, internal or international, is the search for greener pastures or better economic fortunes. Associated with migration is the phenomenon of remittances by migrants from their host countries to their countries of origin. According to the World Bank (2006), remittance flows to developing countries were about \$167 billion in 2005. In fact, remittance flows to developing countries doubled between 2000 and 2005. Officially recorded remittance flows to developing countries were estimated to have reached \$404 billion in 2013, up 3.5 percent over 2012 (World Bank, 2014).

There are several motives for remittances. Lucas and Stark (1985) were the first to note that altruism is not the only motive for remittances. Based on the theory of strategic bequest by Bernheim et al. (1985), one may argue that family members in the home country may use the threat of depriving migrants of their rights to inheritance to secure remittances. Therefore, the prospect of future bequests may incentivize migrants to send remittances to their home country. Cox (1987) argues that altruism and exchange are major motives behind migrants' remittances. In their empirical work, Cox and Rank (1992) found inter-vivos transfers (i.e., transfers between living persons) that were more consistent with exchange than altruism. And Amuedo-Dorantes and Pozo (2006) demonstrate that migrants send remittances to their home country to insure family members and themselves against income losses.

In a related but different strand of the literature, Djajic (1989), Galor and Stark (1990), and Dustman (1997) provide an explanation for the high savings rates of temporary migrants. In particular, their theoretical models which have the flavor of the seminal papers by Leland (1968) 
and Sandmo (1970), find that temporary migrants invest more in precautionary savings the higher is the variance of their future income in the host country and/or home country.

In this paper, we build a model of savings under income uncertainty in the spirit of Leland (1968) and Sandmo (1970). We study not only the effect of income uncertainty on savings but also on remittances. Using recent results in Apps et al. (2014), our main theoretical result is that an immigrant, in response to a first-order decrease in income risk, reduces his savings but increases his current consumption and remittances.

It is well known that the welfare state acts as an insurance mechanism by smoothing consumption for agents in a world of uncertainty (e.g., Barr, 2001). Accordingly, the more generous is the welfare state (cash transfers, size and duration of unemployment benefits, etc), the less is the negative welfare impact of future income risk. In our econometric analysis, we use changes in the size and generosity of the welfare state as a measure of changes in future income risk. This empirical approach is consistent with studies like Engena and Gruber (2001) that use differences in state-contingent income streams available to workers through unemployment insurance programs as a source of variation for testing the presence of a precautionary savings motive. Our econometric results support our theoretical prediction: there is a positive relationship between a more generous welfare state and international remittances (i.e., transfers beyond the borders of the welfare state). This result may be seen as an empirical confirmation of proposition 1 in Apps et al. (2014).

Our paper is related to the literature on whether government charitable transfers fully or partially crowd out private charitable transfers because remittances, in our model, can be relabeled as private charitable transfers (e.g., transfers to charitable organizations like World Vision). In a one-period model with no uncertainty, Andreoni $(1989,1990)$ showed that by 
incorporating warm glow into contributors' preferences, actual government transfers may not fully crowd out private charitable contributions and therefore government debt may have Keynesian effects (i.e., there is no Ricardian equivalence). In a two-period model with income uncertainty in period 2, we obtain a related but different result wherein an increase in expected government transfers (via the welfare state) can lead to an increase in current private transfers.

There is, of course, a literature that studies the interaction between immigrants and the welfare state. Immigrants may be perceived as a drain on the welfare state if they receive taxfinanced income transfers or as a solution to social security crises (e.g., Brücker et al. 2002; Epstein and Hillman, 2003; Giulietti et al. (2013); Nannestad, 2007; Razin, Sadka, and Suwankir, 2011). Furthermore, the welfare state may affect the decision to immigrate (e.g., Levine and Zimmerman, 1999). In the case of intra-state or internal consumption or savings, there have been related studies of the effect of the welfare state (e.g., employment insurance and universal health care programs) on private savings (Hubbard et al., 1995; Gruber and Yelowitz, 1999; Engena and Gruber, 2001). However, there is no work on the effect of the welfare state on cross-border or international remittances. This paper fills this lacuna. Our paper focuses on the effect of the welfare state on remittances not (precautionary) savings. Like Engena and Gruber (2001) and other econometric studies ${ }^{1}$ on savings under uncertainty, our approach obviates the relatively difficult task of estimating income uncertainty (see, for example, Carroll and Samwick (1998) and Engena and Gruber (2001) for a discussion of this difficulty). ${ }^{2}$

\footnotetext{
${ }^{1}$ These studies, some of which are reviewed in Engena and Gruber (2001), use variations in the riskiness of different occupations as proxies for income uncertainty. Carroll (1994) is an example of a paper that tries to directly measure income uncertainty. He finds that income uncertainty has an effect on precautionary savings.

${ }^{2}$ The literature on remittances and migration is fairly large. It considers other issues like the effect of remittances on poverty, human capital formation, and financial development in recipient countries (e.g. Adams and Cuecuecha, 2013; Amuedo-Dorantes and Pozo, 2010; Salas, 2014).
} 
The paper is organized as follows: section 2 presents a model of income uncertainty and remittances. It derives a theoretical prediction which is tested in section 3 . Section 4 concludes the paper.

\section{A model of remittances under income uncertainty}

Consider a risk-averse immigrant in a country who lives for two periods, 1 and 2. In period 1 , he gets a certain (labor) income of $\mathrm{y}_{1}>0$ that must be allocated to consumption, $\mathrm{c}_{1}$, savings, s, and remittances, $r$ (i.e., to his country of origin). In period 2, his income is $\mathrm{y}_{2}$; this second-period income is uncertain with cumulative distribution function (cdf), $\mathrm{G}\left(\mathrm{y}_{2}\right)$. It depends on the states of the world in which he is employed or unemployed. Thus, it includes his labor and non-labor income in different states of the world. ${ }^{3}$ Necessarily, $\mathrm{c}_{1}=\mathrm{y}_{1}-\mathrm{s}-\mathrm{r}$ and his consumption in period 2 is $\mathrm{c}_{2}=\mathrm{y}_{2}+\mathrm{s} .^{4}$

Let the immigrant and his beneficiary in his home country have the same vNM utility function, $\mathrm{u}(\mathrm{w})$, where $\mathrm{u}^{\prime}(\mathrm{w})>0$ and $\mathrm{u}^{\prime \prime}(\mathrm{w})<0$. Following Leland (1968), Levhari and Srinivasan (1969), Kimball (1990), Apps et al. (2014), and many other scholars, we may write expected utility in additively time-separable form as follows:

$$
\mathrm{V}=\mathrm{u}\left(\mathrm{y}_{1}-\mathrm{s}-\mathrm{r}\right)+\beta \mathrm{u}(\mathrm{r})+\delta \mathrm{E}\left(\mathrm{u}\left(\mathrm{y}_{2}+\mathrm{s}\right)\right)
$$

where $E$ is the expectations operator, $\delta \in(0,1]$ is the immigrant's discount factor, and $\beta \in(0,1]$ is the weight that the immigrant places on the utility of his beneficiary.

Note that savings and remittances are modeled differently in (1). While both of them enter negatively in period 1 , only savings are relevant in period 2 , a period distinguished by the

\footnotetext{
${ }^{3}$ This includes various states of the world like when he is working, on strike because of labor dispute beyond his control, and on maternity or paternity leave. It also includes his income in states of the world in which he falls sick or suffers a disability, loses his job, his labor contract is renegotiated, gets a bonus pay, retires, etc.

${ }^{4}$ Without loss of generality, we assume that the interest rate is zero.
} 
fact that there is income uncertainty. This formulation also captures the fact that, for an altruistic immigrant, remittance is also a consumption good in period $1 .^{5}$

One can think of our model as a two-person household model with the immigrant and his beneficiary being the members of the household. Then our model with two consumption goods (i.e., own consumption and remittances) in period 1 can be re-cast within the framework of Apps et al. (2014). ${ }^{6}$ They extend the standard two-period model of savings with risk-averse agents and income uncertainty from a single-person household to a two-person household. They demonstrate the following result:

Proposition 1 (Apps et al., 2014): A first-order increase in risk at the household equilibrium will cause an increase in saving. ${ }^{7}$

In a model with only one consumption good in period 1, proposition 1 implies that an increase in first-order risk $^{8}$ reduces consumption in period 1. But in Apps et al. (2014) with two consumption goods, it does not necessarily follow that the consumption of each member of the household will fall because depending on a member's exogenous utility weight in social welfare (or "bargaining power"), it is conceivable that his/her consumption could increase while the other member's consumption falls by a bigger amount. However, it is easy to show -- although this result is not proven nor emphasized in Apps et al. (2014) - that the consumption of each member of the household falls in period 1 with an increase in first-order risk. This is obvious because each member's consumption is an increasing function of household income net of savings.

We can re-label the period-1 consumption of the members of the household in

\footnotetext{
${ }^{5}$ As mentioned in the introduction, there is a literature on different motives for remittances. We address this issue in subsequent analysis.

${ }^{6}$ We thank Mike Hoy for drawing our attention to this paper.

${ }^{7}$ Eeckhoudt and Schlesinger (2008) prove the same result for a single-person household with only one consumption good in period 1. Notice that risk aversion is sufficient for this result; it does not depend on higher-order derivatives (i.e., third and higher derivatives) of the utility function.

${ }^{8}$ A cumulative distribution function, $F(y)$ represents an increase in first-order risk over a distribution $G(y)$ if $G$ firstorder stochastically dominates F. An increase in first-order risk reduces the mean of a distribution.
} 
Apps et al. (2014) as $r$ (for the immigrant's beneficiary) and $c_{1}$ (for the immigrant) with corresponding individual utility weights $\beta$ and 1 and immediately apply their results. The analogue of the problem in (4) in Apps et al. (2014) is: $\max _{\mathrm{r}, \mathrm{cl}} \Omega=\mathrm{u}\left(\mathrm{c}_{1}\right)+\beta \mathrm{u}(\mathrm{r})$, subject to $c_{1}+r=z$, where $z=y_{1}-s$. It can be shown that, in our model, the analogues of (5) and (6) in Apps et al. (2014) are $\mathrm{u}^{\prime}\left(\mathrm{c}_{1}\right)=\beta \mathrm{u}^{\prime}(\mathrm{r})$ and $\mathrm{r}^{\prime}(\mathrm{z})=\mathrm{u}^{\prime \prime}(\mathrm{z}-\mathrm{r}) /\left[\mathrm{u}^{\prime \prime}(\mathrm{z}-\mathrm{r})+\beta \mathrm{u}^{\prime \prime}(\mathrm{r})\right]>0$, respectively. Then noting that $\mathrm{z}=\mathrm{y}_{1}-\mathrm{s}$ and applying proposition 1 in Apps et al. (2014), it follows that, in equilibrium, the immigrant's own consumption, $\mathrm{c}_{1}^{*}$, and remittances, $\mathrm{r}^{*}$, both fall as first-order risk increases. ${ }^{9}$ A fall in the expected size or generosity of the welfare state (e.g., smaller social transfers) leads to an increase in first-order income risk. That is, all other states being equal, income is lower in future states of the world with negative labor income shocks like being sick, losing your job, and the arrival of a child (maternity or paternity leave) ${ }^{10}$ because the welfare state is less generous in these states. In effect, the fall in the generosity of the welfare state shifts the distribution of future income to the left (i.e., the original distribution, $\mathrm{G}\left(\mathrm{y}_{2}\right)$, first-order stochastically dominates the new distribution, $\left.\mathrm{F}\left(\mathrm{y}_{2}\right)\right)$. Accordingly, the following result holds:

\footnotetext{
${ }^{9}$ Proposition 2 in Apps et al. (2014) is also applicable to our model. In this case, consumption and remittances fall if the immigrant is prudent (i.e., the third derivative of his utility function is positive) and there is an increase in second-order risk (i.e., a mean-preserving spread in the probability distribution of future income). This is because the agent increases his savings in response to an increase in second-order risk. For the same result in the context of a single-person household, see Rothschild and Stiglitz (1971) and Kimball (1990). Crainich et al. (2013) showed that risk lovers are also prudent and are willing to accumulate precautionary savings. This led them to conclude that prudence is a very widespread trait of behavior because it is shared by both risk-loving and risk-averse agents. ${ }^{10} \mathrm{Apps}$ et al. (2014) briefly discussed the implications of their proposition 1 by applying it to the income risk of a household that is expecting a child (i.e., paternity or maternity leave).
} 
Proposition 2: Suppose remittance is a pure consumption good. Then as the expected generosity of the welfare state falls, an immigrant increases his saving but decreases his remittances and own consumption in the current period. Conversely, an increase in the expected generosity of the welfare state increases remittances and an immigrant's own consumption in the current period but decreases his saving.

In our subsequent empirical analysis, we test proposition 2 above. This may be seen as a test of proposition 1 in Apps et al. (2014). However, the relationship between the welfare state and international remittances in and of itself an independent and interesting topic.

It is important to emphasize that proposition 2 does not imply that a part of any actual transfers received by immigrants under the welfare state (i.e., transfers in period 2 in the event of a bad income shock) is remitted to their families in the countries of origin. Instead, our point is that to the extent that these transfers minimize the negative welfare effect of a bad income shock in the future, this expected generosity of the welfare state affects current transfers. Furthermore, given the huge amount of international remittances (i.e., over $\$ 400$ billion in 2013), it is hard to imagine that those who are unemployed or are out of the work force and receive employment benefits, pensions, social assistance transfers, old-age security payments, etc account for a significant share of these transfers. At best, their transfers are a very, very small proportion of total transfers. Those working in the welfare state are the main drivers behind the phenomenon of high international remittances.

\subsection{Further remarks}

We have assumed that the immigrant sends remittances for altruistic reasons. However, consistent with other motives for remittances discussed in section 1, it is possible that a part of 
remittances may be for investment or savings in the migrant's country of origin (e.g., to build a house for later consumption during his retirement in his home country). However, it is possible to isolate a savings motive from a consumption motive because, if an effect exists, our comparative statics results show that savings and remittance move in opposite directions in response to changes in the welfare state. If indeed remittances are for investment or savings in the migrant's home country, then a less generous welfare state should lead to an increase in remittances by an immigrant. ${ }^{11}$ Therefore, if we observe an increase in remittances in response to a more generous welfare state in the host country, ${ }^{12}$ it is reasonable to conclude that remittances are for the purpose of consumption in the home country of immigrants.

To the extent that only immigrants with permanent residency status or work permits are eligible for the benefits of the welfare state, the effect of the welfare state on remittances is only applicable to certain groups of immigrants. Migrants who are part of guest worker programs are not eligible for the benefits of the welfare state. However, immigrants with work permits but without permanent residency status may qualify for unemployment benefits. It is also important to make a distinction between a temporary immigrant and an immigrant with a temporary residency status. For example, there are immigrants who have permanent residency status in their host countries but have intentions of returning to their home countries (e.g., after 5 to 20 years abroad). So it does not necessarily follow that temporary immigrants are not eligible for the benefits of the welfare state. Immigrants who have permanent residency status but intend to return to their home country or have temporary residency status will tend to remit for

\footnotetext{
${ }^{11}$ Obviously, this conclusion holds if the immigrant intends to return home or do so with a sufficiently high probability. But suppose the immigrant does not intend to return. Then we should find, consistent with our altruistic model, that a less generous welfare state should lead to a decrease in remittances.

${ }^{12}$ Dustmann (1997) considers a model in which a temporary migrant's future income in both the host and home countries is subject to uncertainty. Uncertainty in future income in the immigrant's home country has no connection to the welfare state in our analysis because an immigrant's eligibility for the benefits of the welfare state of the host country only kicks when s/he suffers a negative income shock in the host country or the welfare state in the host country protects him/her from the occurrence of negative shocks (e.g., employment protection) in the host country.
} 
investment/insurance purposes while those who have permanent residency status and do not intend to return permanently to their home countries will remit for consumption purposes (e.g., to help relatives or friends at home). In any case, if we observe an effect of changes in the welfare state on remittances, it is reasonable to conclude that these remittances are largely driven by the actions of immigrants who are eligible for the benefits of the welfare state. ${ }^{13}$ And depending on the direction of the effect, we can, as argued above, determine whether the remittances are for pure consumption or savings in the home country. However, the motive behind remittances is not our primary focus. We are primarily interested in the relationship between the welfare state and remittances.

\subsection{Data}

We use an unbalanced panel data from a sample of 168 remittance recipient countries and 34 OECD-member countries covering a 50-year period from 1961 to $2010 .^{14}$ In this section, we only comment on the main variables of interest and refer the reader to table 1 for a description of the rest of the variables.

Our dependent variable is remittance flow received by country $i$ from country $j$ in current US dollars at a given time. There is no credible national data on bilateral remittances. Thus, we rely on the methods of estimating bilateral remittances described in Ratha and Shaw (2007). ${ }^{15}$ The bilateral remittances data were computed using annual remittances data and bilateral migration matrices sourced from World Development Indicators and the World Bank, respectively.

\footnotetext{
${ }^{13} \mathrm{We}$ are cognizant of the fact that some native-born citizens, albeit very few, in rich countries also send remittances to poorer countries.

${ }^{14}$ The countries in our sample are listed in appendices $\mathrm{A}$ and $\mathrm{B}$.

${ }^{15}$ These methods are fully described in appendix $C$.
} 
Our principal independent variable is a measure of the size or generosity of the welfare state. We use five different measures. ${ }^{16}$ The first indicator we use is the size of government, measured by the government's consumption share of a country's GDP (Penn World Table 6.2). The second measure is a country's total social welfare expenditures as a percentage of its GDP (OECD, 2009). Third, we use the degree of labor market regulation, measured as an index of the overall level of "Employment Protection Legislation" developed by the OECD (2004). It consists of three components: regulations governing the terms and conditions of permanent + contracts in case of individual dismissals, additional provisions in the face of mass layoffs, and regulations governing the possibility of hiring on temporary contracts. Fourth, we use pension generosity, a measure developed by Scruggs (2005) where higher values indicate more generosity. Fifth and finally, we use public expenditure on social benefits other than social transfers in kind as a percentage of GDP. This consists of all cash transfers, including social insurance payments and social assistance benefits, provided by government units and social security funds. For all five independent variables, larger values indicate a more generous or bigger welfare state. Therefore, as stated in proposition 1, we expect a positive relationship between each of our measures of the welfare state and remittances.

To construct our panel dataset we averaged annual remittance data for every 10 years beginning from 1961-1970, and then transformed it into bilateral remittance using a method in Ratha and Shaw (2007) ${ }^{17}$ Likewise, the five measures of the size of the welfare state were each averaged every ten years. The dataset contains a total of 17,760 bilateral remittance observations. Depending on the other control variables, our regressions were based on at least 6,374 observations and, in some cases, there were more than 13,000 observations.

\footnotetext{
${ }^{16}$ See Table 6 for a correlation matrix.

${ }^{17}$ These methods are fully described in appendix C.
} 


\subsection{Econometric Analysis}

Denote the welfare state at time $t$ by $\mathrm{W}_{\mathrm{t}}$. In what follows, we assume that at time $\mathrm{t}$ an immigrant's expectation of the welfare state at time $t+1$ is $\mathrm{E}_{\mathrm{t}}\left(\mathrm{W}_{\mathrm{t}+1}\right)=\mathrm{W}_{\mathrm{t}}$. We therefore regress remittance flows in period t on the welfare state at time t. In particular, we model remittance flows using the following econometric specification:

$\log \left(\mathrm{R}_{\mathrm{ijt}}\right)=\alpha+\phi \log \left(\mathrm{W}_{\mathrm{jt}}\right)+\omega \mathrm{X}_{\mathrm{ijt}}+\mu_{\mathrm{i}}+\eta_{\mathrm{j}}+\lambda_{\mathrm{t}}+\varepsilon_{\mathrm{ijt}}$,

where $R_{\mathrm{ijt}}$ is the total amount of remittances received by country $\mathrm{i}$ from country $\mathrm{j}$ at time period $t$ expressed in dollars, averaged every 10 years from 1961-2010; $\mathrm{W}_{\mathrm{jt}}$ is a measure of the welfare state in country $\mathrm{j}$ at time $\mathrm{t}$; and $\mathrm{X}_{\mathrm{ijt}}$ denotes other (control) factors that could influence remittance flows (i.e., stock of migrants from country $i$ in country $j$ at time $t$, per capita GDP of host country, ${ }^{18}$ distance between host and recipient countries, etc), $\mu_{\mathrm{i}}$ are recipient country fixed effects, $\eta_{\mathrm{j}}$ are host country fixed effects, $\lambda_{\mathrm{t}}$ are time fixed effects, and $\varepsilon_{\mathrm{ijt}}$ is a standard error term. We are interested in the coefficient $\phi$. Our theoretical model predicts that $\phi>0$ if remittance is a pure consumption good.

Our baseline fixed effects regressions show that our theoretical prediction is supported when our measure of the welfare state is (a) government's consumption share of a country's GDP, (b) social welfare expenditures, (c) pension generosity, or (d) public expenditure on social benefits. In all four cases, our estimate of $\phi$ is positive and statistically significant at either the $1 \%$ or $10 \%$ level. The estimated coefficient for employment protection has the right sign but is not statistically significant. These results are presented in table 2 .

For some country pairs $\mathrm{i}$ and $\mathrm{j}, \mathrm{R}_{\mathrm{ijt}}=0$ for some $\mathrm{t}$. To address this truncation of our dependent variable, we use the Tobit estimator and include time and country dummies, and a constant. As table 3 shows, our Tobit estimates are similar to our fixed effects estimates. This is

\footnotetext{
${ }^{18}$ We use the logarithm of per capita GDP and migrant stock and also lag these two regressors.
} 
not surprising because in all of our regressions, the number of zero observations for remittances was very small (i.e., not more than $5 \%$ ).

The per capita GDP of the host country is an explanatory variable in our regressions. We note that the coefficients of our five welfare state variables (except for the case of employment protection) were positive and significant regardless of whether we included the per capita GDP of the host country in our regressions. Employment protection had a positive but insignificant coefficient regardless of whether we included per capita GDP of the host country in our regressions.

\subsubsection{Instrumental variable regression}

One may argue that our measures of the welfare state may be endogenous and therefore the effects of the welfare state obtained above may not be causal. This potential endogeneity issue can be addressed with an instrumental (IV) approach. Towards this end, we require a variable which is correlated with our welfare state variable but not with the error term. Following Perotti and Kontopoulos (2002), Bawn and Rosenbluth (2006), Baskaran (2013), and many others, we use the number of parties in a government coalition as an instrument or proxy for the welfare state. These papers found that public sectors are larger when coalitions are formed by more political parties. The theory is that in larger coalitions each party is responsible for only a fraction of government decisions and therefore may lead to higher public expenditures because less accountability is borne by each party in the coalition. Thus government fragmentation increases public expenditures. ${ }^{19}$

\footnotetext{
${ }^{19}$ The data were obtained from this website: http://www.parlgov.org/. Since coalition governments are only possible in parliamentary systems of government, countries with presidential systems of government like the United States, South Korea and Mexico had no data and so were not part of the analysis.
} 
Our IV estimates shown in Table $4,{ }^{20}$ support our theoretical prediction when the welfare state is measured by the size of government or employment protection or public expenditures on social benefits but not for the other two measures, although social welfare expenditure is statistically insignificant but has the correct expected sign. Pension generosity has the wrong sign and is significant at the $10 \%$ level. It is, however, important to note that in all of our regressions the welfare state as measured by the size of government or public expenditures on social benefits support our theoretical prediction and social welfare expenditure does not have the wrong sign in any of our regressions.

\subsection{Another channel?}

One may argue that in addition to the channel examined above, the welfare state affects remittances through a second channel. This channel is an immigration effect wherein a more generous welfare state attracts more immigrants and therefore may lead to more remittances. However, countries with more generous welfare states are likely to have more restrictive immigration policies because of the fear of a fiscal drain of immigrants on the welfare state. ${ }^{21}$ In theory then, the effect of the welfare state on remittances through this second channel is ambiguous. To circumvent the issue of determining the net effect of the welfare state on immigrant flows, we took the direct approach of using the actual stock of migrants in a host country at time t. To the extent that it may take some time for an immigrant to have a reasonable financial capacity, we model this second channel by including a one-period lag of the stock of

\footnotetext{
${ }^{20}$ See Table 5 for first-stage regressions.

${ }^{21}$ These interactions between the welfare state and immigration are present in the analysis of Myers and Papageorgiou (2000), Stichnoth (2012), and Speciale (2012). They also evident in some of the papers cited in section 1.
} 
migrants in a host country in our regressions. ${ }^{22}$ This regressor was included in our regressions. Tables 2, 3, and 4 show that the stock of migrants has a positive effect on remittances. For our purpose, the sign of the coefficient of this variable or its significance is not that important. What matters is that the presence of the stock of migrants as a regressor does not nullify the effects of the welfare state on remittances.

\subsubsection{Robustness}

In Tables 7, 8, and 9, we present additional result to check for robustness. In particular, we present regression results for the variables in levels (not logs) in Table 7. Our theory is supported by three out of five measures of the welfare state.

We also present regressions with and without lagged migration and GDP per capita in Tables 8 and 9. By including the contemporaneous bilateral migrant stock and GDP per capita, welfare state variables are no longer significant. Taking out the bilateral migrant stock variables does not change the results from our baseline regression.

\section{Conclusion}

This paper has taken the first step of investigating the relationship between the welfare state and international remittances. Our analysis showed that a more generous welfare state is associated with an increase in international remittances. This suggests that the welfare state has a more far-reaching and transnational effect than previously thought. For example, the benefits of the German, Norwegian, and American welfare states do not accrue to only the beneficiaries

\footnotetext{
${ }^{22}$ To elaborate, our theory is that the welfare state affects immigrant flows and therefore affects the stock of immigrants, $\mathbf{M}_{t}$, with a lag or new immigrants take a while to improve their financial ability in the host country. Formally, $\mathrm{W}_{t}$ affects $\mathrm{M}_{\mathrm{t}+1}$ which, in turn, affects $\mathrm{R}_{\mathrm{t}+2}$. Then it follows that $\mathrm{W}_{\mathrm{t}-2}$ affects $\mathrm{M}_{t-1}$ and thus affects $\mathrm{R}_{\mathrm{t}}$. However, given that we have data on the stock of immigrants, we use the direct effect of $M_{t-1}$ as a regressor on $R_{t}$ rather than the indirect effect of $\mathrm{W}_{\mathrm{t}-2}$ (via its effect on $\mathrm{M}_{\mathrm{t}-1}$ ) on $\mathrm{R}_{\mathrm{t}}$.
} 
within the borders of Germany, Norway, and USA respectively. The beneficiaries may also include those who are not officially eligible for such benefits and who live outside Germany, Norway, and the USA. This may lead to new ways of thinking about the welfare state in a globalized and integrated world. But, as noted above, it is the expected (not actual) generosity of the welfare state that affects remittances. The boundaries of the welfare state are wider. 
Table 1: Descriptive statistics and variable definitions

\begin{tabular}{|c|c|c|c|c|}
\hline Variable & Mean & S.D. & $\mathbf{N}$ & Definition \\
\hline Bilateral remittances & 17.58 & 195.21 & 17,760 & $\begin{array}{l}\text { Remittances received by country i from country } \mathrm{j} \text { in } \\
\text { current US dollars (millions), } 10 \text {-year averages. } \\
\text { Imputation of bilateral remittances data is based } \\
\text { from panel bilateral migration matrices and follows } \\
\text { the method described in Ratha and Shaw (2007). } \\
\text { Annual remittances data sourced from WDI and } \\
\text { Bilateral Migration Matrices sourced from World } \\
\text { Bank, 1961-2010. }\end{array}$ \\
\hline Size of government & 7.21 & 2.51 & 28,512 & $\begin{array}{l}\text { Share of government expenditures to GDP sourced } \\
\text { from PWT, 10-year averages, } 1961-2010 \text {. }\end{array}$ \\
\hline $\begin{array}{l}\text { Social welfare } \\
\text { expenditures }\end{array}$ & 19.96 & 5.16 & 8,448 & $\begin{array}{l}\text { Share of social welfare expenditures to GDP sourced } \\
\text { from OECD, 1993-2010. }\end{array}$ \\
\hline Employment protection & 2.15 & 0.90 & 15,488 & $\begin{array}{l}\text { Degree of labor market regulation, measured as an } \\
\text { index of the overall level of employment protection } \\
\text { legislation" developed by the OECD, 1985-2010. }\end{array}$ \\
\hline Pension generosity & 11.48 & 3.01 & 12,672 & $\begin{array}{l}\text { Measure of pension generosity developed by } \\
\text { Scruggs (2005) where higher values indicate more } \\
\text { generosity, 1971-2002. }\end{array}$ \\
\hline $\begin{array}{l}\text { Public expenditures on } \\
\text { social benefits }\end{array}$ & 13.07 & 3.65 & 18,459 & $\begin{array}{l}\text { Public expenditure on social benefits other than } \\
\text { social transfers in kind, as a percentage of GDP. } \\
\text { Consist of all cash transfers, including social } \\
\text { insurance payments and social assistance benefits, } \\
\text { provided by government units and social security } \\
\text { funds, sourced from OECD,1961-2010. }\end{array}$ \\
\hline Contiguity & 0.02 & 0.13 & 29,920 & $\begin{array}{l}\text { Dummy variable: } 1 \text { if country i share a common } \\
\text { boundary with country j, } 0 \text { otherwise. Sourced from } \\
\text { CEPRII, 1961-2010. }\end{array}$ \\
\hline Common language & 0.10 & 0.30 & 29,920 & $\begin{array}{l}\text { Dummy variable: } 1 \text { if country } \mathrm{i} \text { have the same } \\
\text { official language(s) as country } \mathrm{j}, 0 \text { otherwise. } \\
\text { Sourced from CEPRII, } 1961-2010 \text {. }\end{array}$ \\
\hline Colony & 0.03 & 0.17 & 29,920 & $\begin{array}{l}\text { Dummy variable: } 1 \text { if country } i \text { was a former colony } \\
\text { of country j, } 0 \text { otherwise. Sourced from CEPRII, } \\
1961-2010 \text {. }\end{array}$ \\
\hline Colony after 1945 & 0.02 & 0.13 & 29,920 & $\begin{array}{l}\text { Dummy variable: } 1 \text { if country i was a colony of } \\
\text { country j after 1945, } 0 \text { otherwise. Sourced from } \\
\text { CEPRII, 1961-2010. }\end{array}$ \\
\hline Same country & 0.01 & 0.08 & 29,920 & $\begin{array}{l}\text { Dummy variable: } 1 \text { if country } i \text { and country } j \text { were } \\
\text { the same country, } 0 \text { otherwise. Sourced from } \\
\text { CEPRII, 1961-2010. }\end{array}$ \\
\hline $\begin{array}{l}\text { Distance between capital } \\
\text { cities }\end{array}$ & $7,013.89$ & $4,340.57$ & 29,920 & $\begin{array}{l}\text { Geodesic distances (in kilometers) calculated } \\
\text { following the great circle formula using geographic } \\
\text { coordinates of the capital cities of country i and } \\
\text { country j. Sourced from CEPRII, 1961-2010. }\end{array}$ \\
\hline $\begin{array}{l}\text { Lagged bilateral migrant } \\
\text { stock }\end{array}$ & 9.99 & 96.20 & 23,800 & $\begin{array}{l}\text { Stock of migrants (in thousands) from country i in } \\
\text { country j lagged one period. Bilateral Migration } \\
\text { Matrices sourced from World Bank, 1961-2010. }\end{array}$ \\
\hline $\begin{array}{l}\text { Lagged per capita GDP of } \\
\text { host country }\end{array}$ & 18.19 & 8.81 & 22,258 & $\begin{array}{l}\text { Real per capita GDP of country j (host) in thousands } \\
\text { lagged sourced from PWT, 10-year averages, 1961- } \\
2010 .\end{array}$ \\
\hline
\end{tabular}


Table 2: Effect of welfare state variables on bilateral remittances, fixed effects regressions

\begin{tabular}{|c|c|c|c|c|c|}
\hline $\begin{array}{l}\text { Dependent variable: } \\
\text { Bilateral remittances }(\operatorname{logs})\end{array}$ & (1) & $(2)$ & (3) & (4) & (5) \\
\hline \multirow[t]{2}{*}{ Contiguity } & -0.160 & -0.053 & -0.138 & $-0.269 *$ & $-0.305^{*}$ \\
\hline & $(0.175)$ & $(0.290)$ & $(0.183)$ & $(0.135)$ & $(0.142)$ \\
\hline \multirow[t]{2}{*}{ Common official language } & $0.432 * * *$ & $0.325 * * *$ & $0.407 * * *$ & $0.552 * * *$ & $0.556 * * *$ \\
\hline & $(0.077)$ & $(0.093)$ & $(0.079)$ & $(0.082)$ & $(0.079)$ \\
\hline \multirow[t]{2}{*}{ Colony } & $0.378 * * *$ & 0.229 & $0.458 * * *$ & $0.503 * * *$ & $0.467 * * *$ \\
\hline & $(0.112)$ & $(0.184)$ & $(0.124)$ & $(0.126)$ & $(0.112)$ \\
\hline \multirow[t]{2}{*}{ Colony after 1945} & $0.976 * * *$ & $1.272 * * *$ & $0.738 * * *$ & $0.806 * * *$ & $0.960 * * *$ \\
\hline & $(0.162)$ & $(0.284)$ & $(0.190)$ & $(0.141)$ & $(0.139)$ \\
\hline \multirow[t]{2}{*}{ Same country } & $0.774 *$ & $1.300 *$ & 0.752 & 0.696 & 0.476 \\
\hline & $(0.372)$ & $(0.558)$ & $(0.404)$ & $(0.447)$ & $(0.449)$ \\
\hline \multirow[t]{2}{*}{ Distance between capital cities (logs) } & $-0.503 * * *$ & $-0.578 * * *$ & $-0.510 * * *$ & $-0.596^{* * *}$ & $-0.546 * * *$ \\
\hline & $(0.047)$ & $(0.056)$ & $(0.046)$ & $(0.065)$ & $(0.059)$ \\
\hline \multirow[t]{2}{*}{ Lagged bilateral migrant stock (logs) } & $0.711 * * *$ & $0.751 * * *$ & $0.697 * * *$ & $0.604 * * *$ & $0.633 * * *$ \\
\hline & $(0.016)$ & $(0.025)$ & $(0.018)$ & $(0.017)$ & $(0.019)$ \\
\hline \multirow[t]{2}{*}{ Lagged per capita GDP of host country (logs) } & 0.309 & $1.150 * * *$ & $0.408^{*}$ & -0.279 & 0.154 \\
\hline & $(0.183)$ & $(0.339)$ & $(0.194)$ & $(0.187)$ & $(0.145)$ \\
\hline \multirow[t]{2}{*}{ Size of government (logs) } & $0.990 * * *$ & & & & \\
\hline & $(0.142)$ & & & & \\
\hline \multirow[t]{2}{*}{ Social welfare expenditures $(\operatorname{logs})$} & & $3.295 * * *$ & & & \\
\hline & & $(0.395)$ & & & \\
\hline \multirow[t]{2}{*}{ Employment protection $(\operatorname{logs})$} & & & 0.149 & & \\
\hline & & & $(0.205)$ & & \\
\hline \multirow[t]{2}{*}{ Pension generosity $(\operatorname{logs})$} & & & & $0.433 *$ & \\
\hline & & & & $(0.182)$ & \\
\hline \multirow[t]{2}{*}{ Public expenditures on social benefits (logs) } & & & & & $0.278^{*}$ \\
\hline & & & & & $(0.130)$ \\
\hline Observations & 13,284 & 6,374 & 10,413 & 8,358 & 9,639 \\
\hline Adjusted R squared & 0.758 & 0.804 & 0.792 & 0.807 & 0.793 \\
\hline Recipient country fixed effects & Yes & Yes & Yes & Yes & Yes \\
\hline Source country fixed effects & Yes & Yes & Yes & Yes & Yes \\
\hline Time fixed effects & Yes & Yes & Yes & Yes & Yes \\
\hline
\end{tabular}

Notes: Standard errors, clustered on remittance recipient countries, in parentheses. Asterisks: * significant at $10 \% ; * *$ significant at $5 \% ; * * *$ significant at $1 \%$. 
Table 3: Effect of welfare state variables on bilateral remittances, Tobit regressions.

\begin{tabular}{|c|c|c|c|c|c|}
\hline $\begin{array}{l}\text { Dependent variable: } \\
\text { Bilateral remittances }(\operatorname{logs})\end{array}$ & (1) & (2) & (3) & (4) & $(5)$ \\
\hline \multirow[t]{2}{*}{ Contiguity } & -0.185 & -0.075 & -0.163 & $-0.282 *$ & $-0.320 *$ \\
\hline & $(0.186)$ & $(0.316)$ & $(0.197)$ & $(0.136)$ & $(0.144)$ \\
\hline \multirow[t]{2}{*}{ Common official language } & $0.441 * * *$ & $0.277 * *$ & $0.391 * * *$ & $0.560 * * *$ & $0.568 * * *$ \\
\hline & $(0.079)$ & $(0.094)$ & $(0.080)$ & $(0.082)$ & $(0.080)$ \\
\hline \multirow[t]{2}{*}{ Colony } & $0.366 * *$ & 0.204 & $0.448 * * *$ & $0.504 * * *$ & $0.464 * * *$ \\
\hline & $(0.116)$ & $(0.189)$ & $(0.127)$ & $(0.125)$ & $(0.113)$ \\
\hline \multirow[t]{2}{*}{ Colony after 1945} & $1.010 * * *$ & $1.337 * * *$ & $0.777 * * *$ & $0.811 * * *$ & $0.977 * * *$ \\
\hline & $(0.170)$ & $(0.301)$ & $(0.200)$ & $(0.141)$ & $(0.142)$ \\
\hline \multirow[t]{2}{*}{ Same country } & $0.863^{*}$ & $1.462 *$ & $0.851 *$ & 0.723 & 0.496 \\
\hline & $(0.398)$ & $(0.605)$ & $(0.431)$ & $(0.456)$ & $(0.460)$ \\
\hline \multirow[t]{2}{*}{ Distance between capital cities $(\operatorname{logs})$} & $-0.510 * * *$ & $-0.594 * * *$ & $-0.517 * * *$ & $-0.602 * * *$ & $-0.549 * * *$ \\
\hline & $(0.049)$ & $(0.060)$ & $(0.048)$ & $(0.066)$ & $(0.060)$ \\
\hline \multirow[t]{2}{*}{ Lagged bilateral migrant stock (logs) } & $0.718 * * *$ & $0.773 * * *$ & $0.709 * * *$ & $0.605 * * *$ & $0.636 * * *$ \\
\hline & $(0.017)$ & $(0.025)$ & $(0.019)$ & $(0.017)$ & $(0.019)$ \\
\hline \multirow[t]{2}{*}{ Lagged per capita GDP of host country (logs) } & 0.328 & $1.133 * *$ & $0.410^{*}$ & -0.303 & 0.140 \\
\hline & $(0.195)$ & $(0.350)$ & $(0.199)$ & $(0.191)$ & $(0.149)$ \\
\hline \multirow[t]{2}{*}{ Size of government (logs) } & $1.040 * * *$ & & & & \\
\hline & $(0.149)$ & & & & \\
\hline \multirow[t]{2}{*}{ Social welfare expenditures (logs) } & & $3.493 * * *$ & & & \\
\hline & & $(0.411)$ & & & \\
\hline \multirow[t]{2}{*}{ Employment protection (logs) } & & & 0.149 & & \\
\hline & & & $(0.208)$ & & \\
\hline \multirow[t]{2}{*}{ Pension generosity (logs) } & & & & $0.429 *$ & \\
\hline & & & & $(0.185)$ & \\
\hline \multirow[t]{2}{*}{ Public expenditures on social benefits (logs) } & & & & & $0.308^{*}$ \\
\hline & & & & & $(0.134)$ \\
\hline Observations & 13,284 & 6,374 & 10,413 & 8,358 & 9,639 \\
\hline Share of positive observations & 0.953 & 0.941 & 0.952 & 0.979 & 0.974 \\
\hline
\end{tabular}

Notes: Standard errors, clustered on remittance recipient countries, in parentheses. Asterisks: * significant at $10 \%$; ** significant at $5 \%$; *** significant at $1 \%$. 
Table 4: Effect of welfare state variables on bilateral remittances, instrumental variable regressions.

\begin{tabular}{|c|c|c|c|c|c|}
\hline $\begin{array}{l}\text { Dependent variable: } \\
\text { Bilateral remittances }(\operatorname{logs})\end{array}$ & (1) & (2) & (3) & (4) & (5) \\
\hline \multirow[t]{2}{*}{ Contiguity } & -0.200 & -0.001 & -0.169 & -0.212 & -0.246 \\
\hline & $(0.189)$ & $(0.319)$ & $(0.194)$ & $(0.131)$ & $(0.162)$ \\
\hline \multirow[t]{2}{*}{ Common official language } & $0.312 * * *$ & $0.288 * *$ & $0.384 * * *$ & $0.539 * * *$ & $0.484 * * *$ \\
\hline & $(0.091)$ & $(0.102)$ & $(0.087)$ & $(0.085)$ & $(0.088)$ \\
\hline \multirow[t]{2}{*}{ Colony } & $0.628 * * *$ & 0.306 & $0.488 * * *$ & $0.596 * * *$ & $0.458 * * *$ \\
\hline & $(0.138)$ & $(0.199)$ & $(0.121)$ & $(0.131)$ & $(0.135)$ \\
\hline \multirow[t]{2}{*}{ Colony after 1945} & $0.826 * * *$ & $1.338 * * *$ & $0.883 * * *$ & $0.830 * * *$ & $1.181 * * *$ \\
\hline & $(0.175)$ & $(0.285)$ & $(0.189)$ & $(0.151)$ & $(0.182)$ \\
\hline \multirow[t]{2}{*}{ Same country } & $0.905^{*}$ & $1.477 *$ & $0.862 *$ & 0.746 & 0.366 \\
\hline & $(0.422)$ & $(0.577)$ & $(0.413)$ & $(0.437)$ & $(0.524)$ \\
\hline \multirow[t]{2}{*}{ Distance between capital cities (logs) } & $-0.425 * * *$ & $-0.539 * * *$ & $-0.470 * * *$ & $-0.549 * * *$ & $-0.538 * * *$ \\
\hline & $(0.053)$ & $(0.069)$ & $(0.057)$ & $(0.071)$ & $(0.078)$ \\
\hline \multirow[t]{2}{*}{ Lagged bilateral migrant stock (logs) } & $0.712 * * *$ & $0.730 * * *$ & $0.684 * * *$ & $0.586 * * *$ & $0.602 * * *$ \\
\hline & $(0.017)$ & $(0.028)$ & $(0.019)$ & $(0.021)$ & $(0.026)$ \\
\hline \multirow[t]{2}{*}{ Lagged per capita GDP of host country (logs) } & $0.444 * *$ & $2.487 * * *$ & $2.246 * * *$ & $2.382 *$ & $-4.727 * *$ \\
\hline & $(0.168)$ & $(0.672)$ & $(0.490)$ & $(1.108)$ & $(1.784)$ \\
\hline \multirow[t]{2}{*}{ Size of government $(\operatorname{logs})$} & $7.294 * * *$ & & & & \\
\hline & $(0.783)$ & & & & \\
\hline \multirow[t]{2}{*}{ Social welfare expenditures (logs) } & & -1.649 & & & \\
\hline & & $(1.268)$ & & & \\
\hline \multirow[t]{2}{*}{ Employment protection (logs) } & & & $7.899 * * *$ & & \\
\hline & & & $(1.925)$ & & \\
\hline \multirow[t]{2}{*}{ Pension generosity $(\operatorname{logs})$} & & & & $-3.430 *$ & \\
\hline & & & & $(1.565)$ & \\
\hline \multirow[t]{2}{*}{ Public expenditures on social benefits (logs) } & & & & & $12.682 * *$ \\
\hline & & & & & $(4.611)$ \\
\hline Observations & 11,706 & 5,603 & 9,450 & 7,854 & 9,135 \\
\hline Adjusted R squared & 0.719 & 0.790 & 0.764 & 0.793 & 0.656 \\
\hline Recipient country fixed effects & Yes & Yes & Yes & Yes & Yes \\
\hline Source country fixed effects & Yes & Yes & Yes & Yes & Yes \\
\hline Time fixed effects & Yes & Yes & Yes & Yes & Yes \\
\hline
\end{tabular}

Notes: Standard errors, clustered on remittance recipient countries, in parentheses. Asterisks: * significant at $10 \%$; ** significant at 5\%; *** significant at $1 \%$. Instrument is the number of parties in the winning parliamentary coalition. 
Table 5: Effect of number of parties to welfare state variables (first stage regressions)

\begin{tabular}{|l|l|l|l|l|l|}
\hline & $\begin{array}{c}\text { Size of } \\
\text { government }\end{array}$ & $\begin{array}{c}\text { Social } \\
\text { welfare } \\
\text { expenditures }\end{array}$ & $\begin{array}{c}\text { Poblic } \\
\text { Employment } \\
\text { protection }\end{array}$ & $\begin{array}{c}\text { Pubnsion } \\
\text { Penerosity }\end{array}$ & $\begin{array}{c}\text { expenditure } \\
\text { on social } \\
\text { benefits }\end{array}$ \\
\hline $\begin{array}{l}\text { Number of parties in the } \\
\text { government coalition }\end{array}$ & $-0.0239^{* * *}$ & $-0.0138^{* * *}$ & $0.0061^{* * *}$ & $-0.0072^{* * *}$ & $0.0028^{* *}$ \\
\hline Standard error & $(0.0011)$ & $(0.0002)$ & $(0.0010)$ & $(0.0009)$ & $(0.0011)$ \\
\hline \multicolumn{5}{|l|}{} \\
\hline Observations & 11,706 & 5,603 & 9,450 & 7,854 & 9,135 \\
\hline R squared & 0.7934 & 0.9882 & 0.9705 & 0.9282 & 0.7949 \\
\hline Other controls & Yes & Yes & Yes & Yes & Yes \\
\hline Recipient country fixed effects & Yes & Yes & Yes & Yes & Yes \\
\hline Source country fixed effects & Yes & Yes & Yes & Yes & Yes \\
\hline Time fixed effects & Yes & Yes & Yes & Yes & Yes \\
\hline
\end{tabular}

Notes: Standard errors, clustered on remittance recipient countries, in parentheses. Asterisks: * significant at $10 \% ; * *$ significant at $5 \% ; * * *$ significant at $1 \%$.

\section{Table 6: Correlation matrix (pooled)}

\begin{tabular}{|l|c|c|c|c|c|c|}
\hline & $(1)$ & $(2)$ & $(3)$ & $(4)$ & $(5)$ & $(6)$ \\
\hline Remittances (1) & 1.00 & & & & & \\
\hline Size of government (2) & -0.03 & 1.00 & & & & \\
\hline Social welfare expenditures (3) & 0.16 & 0.20 & 1.00 & & & \\
\hline Employment protection (4) & -0.21 & 0.06 & 0.22 & 1.00 & & \\
\hline Pension generosity (5) & -0.14 & -0.12 & -0.12 & 0.24 & 1.00 & \\
\hline Public expenditures on social benefits (6) & -0.04 & 0.65 & 0.65 & 0.45 & 0.21 & 1.00 \\
\hline
\end{tabular}

Note: Variables expressed in logs. 
Table 7: Effect of welfare state variables on bilateral remittances, fixed effects regressions

\begin{tabular}{|c|c|c|c|c|c|}
\hline $\begin{array}{l}\text { Dependent variable: } \\
\text { Bilateral remittances (levels) }\end{array}$ & (1) & (2) & (3) & (4) & (5) \\
\hline \multirow{2}{*}{ Contiguity } & -7.305 & 42.717 & 8.159 & -7.220 & -8.617 \\
\hline & $(39.002)$ & \begin{tabular}{|l}
$(64.743)$ \\
\end{tabular} & \begin{tabular}{|l}
$(45.329)$ \\
\end{tabular} & $(67.462)$ & $(58.966)$ \\
\hline \multirow[t]{2}{*}{ Common official language } & 6.948 & 14.104 & 8.317 & 4.375 & 8.164 \\
\hline & $(6.974)$ & (12.778) & $(9.497)$ & (10.217) & $(8.897)$ \\
\hline \multirow[t]{2}{*}{ Colony } & -61.381 & -118.655 & -78.984 & -120.350 & -78.387 \\
\hline & $(38.228)$ & $(74.561)$ & $(47.542)$ & $(73.185)$ & $(48.409)$ \\
\hline \multirow{2}{*}{ Colony after 1945} & 21.997 & 128.600 & 46.383 & 77.097 & 35.351 \\
\hline & $(48.947)$ & $(85.627)$ & $(57.616)$ & $(77.617)$ & $(55.934)$ \\
\hline \multirow[t]{2}{*}{ Same country } & 37.621 & 54.081 & 36.363 & 117.382 & 86.182 \\
\hline & (23.443) & \begin{tabular}{|l|}
$(47.239)$ \\
\end{tabular} & $(28.201)$ & $(61.138)$ & $(44.974)$ \\
\hline \multirow{2}{*}{ Distance between capital cities } & -0.000 & -0.000 & -0.000 & -0.000 & -0.000 \\
\hline & $(0.001)$ & $(0.001)$ & $(0.001)$ & $(0.001)$ & $(0.001)$ \\
\hline \multirow[t]{2}{*}{ Lagged bilateral migrant stock } & $0.002 * * *$ & $0.002 * * *$ & $0.002 * * *$ & $0.002 * * *$ & $0.002 * * *$ \\
\hline & $(0.000)$ & $(0.000)$ & $(0.000)$ & $(0.000)$ & $(0.000)$ \\
\hline \multirow[t]{2}{*}{ Lagged per capita GDP of host country } & $0.001 * * *$ & 0.000 & $0.003 * * *$ & $0.002 * *$ & -0.000 \\
\hline & $(0.000)$ & $(0.000)$ & $(0.001)$ & $(0.001)$ & $(0.000)$ \\
\hline \multirow[t]{2}{*}{ Size of government } & -0.165 & & & & \\
\hline & $(0.417)$ & & & & \\
\hline \multirow[t]{2}{*}{ Social welfare expenditures } & & $15.182 * * *$ & & & \\
\hline & & $(4.344)$ & & & \\
\hline \multirow[t]{2}{*}{ Employment protection } & & & $14.557^{*}$ & & \\
\hline & & & $(7.154)$ & & \\
\hline \multirow[t]{2}{*}{ Pension generosity } & & & & -0.812 & \\
\hline & & & & $(0.921)$ & \\
\hline \multirow[t]{2}{*}{ Public expenditures on social benefits } & & & & & $2.581 * * *$ \\
\hline & & & & & $(0.765)$ \\
\hline Observations & 16,495 & 7,271 & 12,321 & 9,252 & 10,997 \\
\hline Adjusted R squared & 0.721 & 0.785 & 0.744 & 0.737 & 0.728 \\
\hline Recipient country fixed effects & Yes & Yes & Yes & Yes & Yes \\
\hline Source country fixed effects & Yes & Yes & Yes & Yes & Yes \\
\hline Time fixed effects & Yes & Yes & Yes & Yes & Yes \\
\hline
\end{tabular}

Notes: Standard errors, clustered on remittance recipient countries, in parentheses. Asterisks: * significant at $10 \% ; * *$ significant at $5 \% ; * * *$ significant at $1 \%$. 
Table 8: Effect of welfare state variables on bilateral remittances, fixed effects regressions with contemporaneous bilateral migrant stock and GDP per capita of host country

\begin{tabular}{|c|c|c|c|c|c|}
\hline $\begin{array}{l}\text { Dependent variable: } \\
\text { Bilateral remittances (logs) }\end{array}$ & $(1)$ & $(2)$ & (3) & $(4)$ & $(5)$ \\
\hline \multirow[t]{2}{*}{ Contiguity } & -0.003 & 0.072 & -0.016 & $-0.020 *$ & $-0.022 *$ \\
\hline & $(0.010)$ & $(0.040)$ & $(0.015)$ & $(0.008)$ & $(0.010)$ \\
\hline \multirow[t]{2}{*}{ Common official language } & -0.005 & -0.004 & 0.008 & -0.006 & -0.002 \\
\hline & $(0.010)$ & $(0.016)$ & $(0.010)$ & $(0.009)$ & $(0.011)$ \\
\hline \multirow[t]{2}{*}{ Colony } & 0.011 & -0.013 & -0.006 & -0.016 & -0.024 \\
\hline & $(0.017)$ & $(0.033)$ & $(0.011)$ & $(0.013)$ & $(0.014)$ \\
\hline \multirow[t]{2}{*}{ Colony after 1945} & -0.017 & $-0.086^{*}$ & -0.010 & -0.022 & -0.021 \\
\hline & $(0.014)$ & $(0.037)$ & $(0.016)$ & $(0.017)$ & $(0.018)$ \\
\hline \multirow[t]{2}{*}{ Same country } & 0.026 & -0.015 & -0.016 & 0.005 & 0.012 \\
\hline & $(0.057)$ & $(0.076)$ & $(0.028)$ & $(0.011)$ & $(0.013)$ \\
\hline \multirow[t]{2}{*}{ Distance between capital cities (logs) } & 0.011 & $0.043 * * *$ & 0.016 & 0.013 & 0.018 \\
\hline & $(0.009)$ & $(0.012)$ & $(0.008)$ & $(0.010)$ & $(0.011)$ \\
\hline \multirow[t]{2}{*}{ Bilateral migrant stock (logs) } & $1.010 * * *$ & $1.022 * * *$ & $1.008 * * *$ & $1.019 * * *$ & $1.017 * * *$ \\
\hline & $(0.006)$ & $(0.007)$ & $(0.005)$ & $(0.008)$ & $(0.008)$ \\
\hline \multirow[t]{2}{*}{ GDP per capita of host country (logs) } & 0.047 & -0.013 & 0.019 & -0.005 & 0.027 \\
\hline & $(0.033)$ & $(0.044)$ & $(0.046)$ & $(0.029)$ & $(0.026)$ \\
\hline \multirow[t]{2}{*}{ Size of government (logs) } & 0.018 & & & & \\
\hline & $(0.026)$ & & & & \\
\hline \multirow[t]{2}{*}{ Social welfare expenditures (logs) } & & -0.039 & & & \\
\hline & & $(0.051)$ & & & \\
\hline \multirow[t]{2}{*}{ Employment protection (logs) } & & & -0.017 & & \\
\hline & & & $(0.025)$ & & \\
\hline \multirow[t]{2}{*}{ Pension generosity $(\operatorname{logs})$} & & & & 0.021 & \\
\hline & & & & $(0.028)$ & \\
\hline \multirow[t]{2}{*}{ Public expenditures on social benefits $(\operatorname{logs})$} & & & & & -0.010 \\
\hline & & & & & $(0.024)$ \\
\hline Observations & 14388 & 6410 & 10763 & 8641 & 10298 \\
\hline Adjusted R squared & 0.966 & 0.976 & 0.969 & 0.965 & 0.965 \\
\hline Recipient country fixed effects & Yes & Yes & Yes & Yes & Yes \\
\hline Source country fixed effects & Yes & Yes & Yes & Yes & Yes \\
\hline Time fixed effects & Yes & Yes & Yes & Yes & Yes \\
\hline
\end{tabular}

Notes: Standard errors, clustered on remittance recipient countries, in parentheses. Asterisks: * significant at $10 \%$; ** significant at $5 \%$; *** significant at $1 \%$. The dependent variable has been re-scaled to millions. 
Table 9: Effect of welfare state variables on bilateral remittances, fixed effects regressions without bilateral migrant stock

\begin{tabular}{|l|l|l|l|l|l|}
\hline $\begin{array}{l}\text { Dependent variable: } \\
\text { Bilateral remittances (logs) }\end{array}$ & $(1)$ & $(2)$ & $(3)$ & $(4)$ & $(5)$ \\
\hline Contiguity & $2.002^{* * *}$ & $1.998^{* * *}$ & $2.033^{* * *}$ & $1.924^{* * *}$ & $1.841^{* * *}$ \\
\hline & $(0.354)$ & $(0.422)$ & $(0.345)$ & $(0.389)$ & $(0.369)$ \\
\hline Common official language & $1.797^{* * *}$ & $1.709^{* * *}$ & $1.798^{* * *}$ & $1.846^{* * *}$ & $1.890^{* * *}$ \\
\hline & $(0.129)$ & $(0.153)$ & $(0.139)$ & $(0.194)$ & $(0.164)$ \\
\hline Colony & $1.381^{* * *}$ & $0.913^{* * *}$ & $1.190^{* * *}$ & $0.983^{* *}$ & $1.117^{* * *}$ \\
\hline & $(0.233)$ & $(0.249)$ & $(0.226)$ & $(0.324)$ & $(0.258)$ \\
\hline Colony after 1945 & $1.891^{* * *}$ & $1.853^{* * *}$ & $1.884^{* * *}$ & $1.604^{* *}$ & $1.841^{* * *}$ \\
\hline & $(0.426)$ & $(0.405)$ & $(0.408)$ & $(0.508)$ & $(0.441)$ \\
\hline Same country & $2.109^{* * *}$ & $3.297^{* * *}$ & $2.417^{* * *}$ & $1.919^{* * *}$ & $1.901^{* * *}$ \\
\hline & $(0.494)$ & $(0.617)$ & $(0.478)$ & $(0.552)$ & $(0.478)$ \\
\hline Distance between capital cities (logs) & -0.267 & -0.333 & -0.239 & -0.055 & 0.033 \\
\hline & $(0.202)$ & $(0.203)$ & $(0.208)$ & $(0.294)$ & $(0.267)$ \\
\hline Bilateral migrant stock (logs) & - & - & - & - & - \\
\hline & - & - & - & - & - \\
\hline GDP per capita of host country (logs) & $0.542^{* *}$ & $2.389^{* * *}$ & 0.148 & -0.205 & $1.235^{* * *}$ \\
\hline & $(0.202)$ & $(0.324)$ & $(0.240)$ & $(0.283)$ & $(0.216)$ \\
\hline Size of government (logs) & $1.415^{* * *}$ & & & & \\
\hline & $(0.139)$ & & & & \\
\hline Social welfare expenditures (logs) & & $1.615^{* * *}$ & & & \\
\hline & & $(0.309)$ & & & \\
\hline Employment protection (logs) & & & -0.122 & & \\
\hline & & & $(0.247)$ & & \\
\hline Pension generosity (logs) & & & & 0.200 & \\
\hline & & & & $(0.223)$ & \\
\hline Public expenditures on social benefits (logs) & & & & & $-1.128^{* * * *}$ \\
\hline & & & & & $(0.192)$ \\
\hline Observations & 16528 & 7300 & 12354 & 9270 & 11019 \\
\hline Adjusted R squared & 0.684 & 0.717 & 0.698 & 0.679 & 0.667 \\
\hline Recipient country fixed effects & Yes & Yes & Yes & Yes & Yes \\
\hline Source country fixed effects & Yes & Yes & Yes & Yes & Yes \\
\hline Time fixed effects & Yes & Yes & Yes & Yes & Yes \\
\hline & & & & \\
\hline & & & & & \\
\hline
\end{tabular}

Notes: Standard errors, clustered on remittance recipient countries, in parentheses. Asterisks: * significant at $10 \%$; * significant at $5 \%$; ** significant at $1 \%$. 


\section{Appendix A: List of remittance recipient countries}

Afghanistan, Albania, Algeria, Angola, Antigua and Barbuda, Argentina, Armenia, Australia, Austria, Azerbaijan, Bahamas, Bahrain, Bangladesh, Barbados, Belarus, Belgium, Belize, Benin, Bermuda, Bhutan, Bolivia, Bosnia and Herzegovina, Botswana, Brazil, Brunei, Bulgaria, Burkina Faso, Burundi, Cambodia, Cameroon, Canada, Cape Verde, Central African Republic, Chad, Chile, China, Colombia, Comoros, Congo, Costa Rica, Cote Ivory, Croatia, Cuba, Cyprus, Czech Republic, Democratic Rep of Congo, Denmark, Djibouti, Dominica, Dominican Republic, Ecuador, Egypt, El Salvador, Equatorial Guinea, Eritrea, Estonia, Ethiopia, Fiji, Finland, France, Gabon, Gambia, Georgia, Germany, Ghana, Greece, Grenada, Guatemala, Guinea, GuineaBissau, Guyana, Haiti, Honduras, Hungary, Iceland, India, Indonesia, Iran, Iraq, Ireland, Israel, Italy, Jamaica, Japan, Jordan, Kazakhstan, Kenya, Kiribati, Kuwait, Kyrgyzstan, Laos, Latvia, Lebanon, Lesotho, Liberia, Libya, Lithuania, Luxembourg, Macedonia, Madagascar, Malawi, Malaysia, Maldives, Mali, Malta, Mauritania, Mauritius, Mexico, Moldova, Mongolia, Montenegro, Morocco, Mozambique, Namibia, Nepal, Netherlands, New Zealand, Nicaragua, Niger, Nigeria, Norway, Oman, Pakistan, Panama, Papua New Guinea, Paraguay, Peru, Philippines, Poland, Portugal, Qatar, Romania, Russia, Rwanda, Saint Lucia, Saint Vincent and Grenadines, Samoa, Saudi Arabia, Senegal, Seychelles, Sierra Leone, Singapore, Slovak Republic, Slovenia, Somalia, South Africa, South Korea, Spain, Sri Lanka, Sudan, Suriname, Swaziland, Sweden, Switzerland, Syria, Tajikistan, Tanzania, Thailand, Togo, Tonga, Trinidad and Tobago, Tunisia, Turkey, Turkmenistan, Uganda, Ukraine, United Arab Emirates, United Kingdom, United States, Uruguay, Uzbekistan, Venezuela, Vietnam, Yemen, Zambia, and Zimbabwe.

\section{Appendix B: List of remittance source countries}

Australia, Austria, Belgium, Canada, Chile, Czech Republic, Denmark, Estonia, Finland, France, Germany, Greece, Hungary, Iceland, Ireland, Israel, Italy, Japan, Luxembourg, Mexico, Netherlands, New Zealand, Norway, Poland, Portugal, Slovak Republic, Slovenia, South Korea, Spain, Sweden, Switzerland, Turkey, United Kingdom, and United States. 


\section{Appendix C: Estimating bilateral remittances}

The available remittances data from the World Bank are reported in the aggregate and show the amount of remittances received by countries regardless of the source. Credible national data on bilateral remittances are difficult to find. There are bilateral remittance data reported by international banks but these data may have measurement errors. ${ }^{23}$ Hence, in an attempt to produce reliable data, scholars have developed different methods to derive bilateral remittance flows using bilateral migrant stock data and assumptions about the remittance behavior of migrants (Harrison, et al, 2005; Ratha and Shaw, 2007; Mohapatra and Ratha, 2010).

As noted in the main text, we used a method in Ratha and Shaw (2007). In particular, we calculated bilateral remittances by allocating remittances received by each recipient country among the countries of destination of its migrants. To be precise, define $\mathrm{m}_{\mathrm{ijt}}$ as the stock of migrants from country $i$ in destination country $j$ at time $t$ and $R_{i t}$ as aggregate remittance to country $i$ at time $t$. Then the estimated bilateral remittances, $R_{\mathrm{ijt}}$, received by country $\mathrm{i}$ from country $\mathrm{j}$ in period $\mathrm{t}$ is given by:

$$
R_{i j t}=\frac{m_{i j t}}{\sum_{j} m_{i j t}} \times R_{i t},
$$

The migrant stock data were sourced from the World Bank's Bilateral Migration Matrices which are available every ten years from 1960 . We averaged the aggregate remittance data every ten years starting 1960 in order to match the availability for the bilateral migrant stock data. The aggregated remittances data (in US dollars, calendar year prices) were sourced from the World

\footnotetext{
${ }^{23}$ The measurement error is based on the notion that some of the remitted funds may have been attributed to a country other than the actual source country. See Ratha (2005) for a discussion on the shortcomings of using data sourced from international banks.
} 
Bank Development Indicators. Finally, since data are available for every ten-year period, the $t$ subscript indicates time periods every ten years beginning 1960.

\section{References}

Adams, R.H., and Cuecuecha, A. (2013). The Impact of Remittances on Investment and Poverty in Ghana. World Development 50: 24 - 40.

Amuedo-Dorantes, C. and Pozo, S. (2002). Precautionary saving by young immigrants and young natives. Southern Economic Journal 69: 48-71.

Amuedo-Dorantes, C. and Pozo, S. (2010). Accounting for Remittance and Migration Effects on Children's Schooling. World Development 38: 1747 - 1759.

Andreoni, J. (1989). Giving with Impure Altruism: Applications to Charity and Ricardian Equivalence. Journal of Political Economy 97: 1447-1458.

Andreoni, J. (1990). Impure Altruism and Donations to Public Goods: A Theory of Warm-Glow. Economic Journal 100: 464-477.

Apps, P., Andrienko, Y., and Rees, R. (2014). Risk and precautionary saving in two-person households. American Economic Review 104: 1040-1046.

Barr, N. (2001). The welfare state as piggy bank: information, risk, uncertainty and the role of the state. Oxford: Oxford University Press.

Bawn, K. and F. Rosenbluth (2006). Short versus Long Coalitions: Electoral Accountability and the Size of the Public Sector. American Journal of Political Science 50 (2), 251-265.

Bernheim, B. D., Shleifer, A. and Summers, L. H. (1985). The strategic bequest motive. Journal of Political Economy 93: 1045-1076.

Baskaran, T. (2013). Coalition governments, cabinet size, and the common pool problem: Evidence from the German states. European Journal of Political Economy 32: 356-376.

Brücker, H., Epstein, G.C. Giulietti, M. Guzi and M. Kahanec, McCormick, B., Saint-Paul, G., Venturini, A., and Zimmerman, K. (2002). Managing Migration in the European Welfare State, in: T. Boeri, G. Hanson, and B. McCormick (Eds.), Immigration Policy and the Welfare System. Oxford University Press, Oxford, Part I, 1-167.

Carroll, C.D. (1994). How does future income affect current consumption? Quarterly Journal of Economics 109: 111-147. 
Carroll, C.D., and Samwick, A.A. (1998). How Important Is Precautionary Saving? Review of Economics and Statistics 80: 410-419.

Cox, D. (1987). Motives for private transfers. Journal of Political Economy 95: 508-546.

Cox, D., Eser, Z. and Jimenez, E. (1987). Motives for private transfers over the life cycle: an analytical framework and evidence for Peru. Journal of Development Economics 55: 57-80.

Cox, D. and Rank, M. R. (1992). Inter-vivos transfers and intergenerational exchange. Review of Economics and Statistics 74: 305-314.

Crainich, D., Eeckhoudt, L., and Trannoy, A. (2013). Even (mixed) risk lovers are prudent. American Economic Review 103: 1529-1535.

Djajic, S. (1989). Migrants in a guest worker system. Journal of Development Economics 31: 327-339.

Dustman, C. (1997). Return migration, uncertainty, and precautionary savings. Journal of Development Economics 52: 296-316.

Eeckhoudt, L., and Schlesinger, H. (2008). Changes in risk and demand for saving. Journal of Monetary Economics 55: 1329-1336.

Engena, E.M., and Gruber, J. (2001). Unemployment insurance and precautionary saving. Journal of Monetary Economics 47: 545-579.

Epstein, G.S., and Hillman, A. (2003). Unemployed immigrants and voter sentiment in the welfare state. Journal of Public Economics 87: 1641-1655.

Galor, O. and Stark, O. (1990). Migrants' savings, the probability of return migration and migrants' performance. International Economic Review 31: 463-467.

Gruber, J. and Yelowitz, A. (1999). Public health insurance and private savings. Journal of Political Economy 107: 1249-1274.

Harrison, A., Britton, T. and A, Swanson. (2004). Working Abroad - the benefits flowing from nationals working in other economies. Round Table on Sustainable Development. OECD.

Hubbard, G., Skinner, J., and Zeldes, S. (1995). Precautionary saving and social insurance. Journal of Political Economy 103: 360-399.

Kimball, M. S. (1990). Precautionary saving in the small and in the large. Econometrica 58: 5373. 
Leland, H. E. (1968). Saving and uncertainty: the precautionary demand for saving. Quarterly Journal of Economics 82: 465-473.

Levhari, D., and Srinivasan, T.N. (1969). Optimal savings under uncertainty. Review of Economic Studies 36: 153-163.

Levine, P. B., and Zimmerman, D.J. (1999). An empirical analysis of the welfare magnet Debate using the NLSY. Journal of Population Economics 12: 391 - 409.

Lucas, R. E. B., and Stark, O. (1985). Motivations to remit: evidence from Botswana. Journal of Political Economy 93: 901-918.

Mohapatra, S., \& Ratha, D. (2010). Forecasting migrant remittances during the global financial crisis. Migration Letters 7: 203-213.

Myers, G.M., and Papageorgiou, Y.Y. (2000). Immigration control and the welfare state. Journal of Public Economics 75: 183-207.

Nannestad, P. (2007). Immigration and welfare states: a survey of 15 years of research. European Journal of Political Economy 23: 512-532.

Perotti, R., Kontopoulos, Y. (2002). Fragmented fiscal policy. Journal Public Economics 86: 191-222.

Ratha, D. (2005) Worker Remittances: An Important and Stable Source of External Development Finance. In S. Maimbo and D. Ratha (Eds.), Remittances: Development Impact and Future Prospects. Washington, D.C.: The World Bank.

Ratha, D. and Shaw, W. (2007). South-south migration and remittances. The World Bank Working Paper No. 102.

Razin, A., Sadka, E., and Suwankiri, B. (2011). Migration and the welfare State: politicaleconomy policy formation. Cambridge: MIT Press.

Rothschild, M., and Stiglitz, J.E. (1971). Increasing risk II: its economic consequences. Journal of Economic Theory 3: 66-84.

Salas, V.B. (2014). International Remittances and Human Capital Formation. World Development 59: 224 - 237.

Sandmo, A. (1970). The effect of uncertainty on savings decisions. Review of Economic Studies 37: 353-360.

Scruggs, L. (2005). Comparative welfare entitlements dataset. Department of Political Science, University of Connecticut. 
Speciale, B. (2012). Does immigration affect public education expenditures? Quasi-experimental evidence. Journal of Public Economics 96: 773-783.

Stichnoth, H. (2012). Does immigration weaken natives' support for the unemployed? Evidence from Germany. Public Choice 151: 631-654.

World Bank (2006). Global economic prospects 2006: economic implications of remittances and migration. World Bank, Washington, DC.

World Bank (2014). Migration and development brief 22. World Bank, Washington, DC. 